\title{
PERUBAHAN POLA PENDIDIKAN DI MASA COVID 19
}

\author{
Nurhasanah, S.Pd \\ Mahasis wa Magister Program Studi Pendidikan IPS \\ Email: belaraisa0@gmail.com
}

\begin{abstract}
ABSTRAK
Akhir tahun 2019 munculnya wabah atau virus baru yang bernama Covid 19 yang melanda kota wuhan Republik Rakyat Tiongkok yang pada pada akhirnya dampaknya juga sampai keseluruh dunia dengan begitu cepat, wabah ini sangat berbahaya karena bisa mengakibatkan kematian dan akibat wabah ini juga angka kematian begitu tinggi hampir diseluruh dunia begitu pula dengan Negara Indonesia yang terdampak pula wabah ini yang masuk diawal tahun 2020, hal ini sangat berdampak besar di kehidupan ekonomi,sosial,budaya dan politik di Indonesia, pada tulisan ini penulis akan mempaparkan akibat virus covid yang terjadi di Indonesia terutama di bidang pendidikan yang secara umum begitu berubah sangat drastis dari pola lama yaitu tatap muka dengan menyesuaikan kurikulum pembelajaran yang ada berubah kepada pola pembelajaran daring yang mengarah pada penggunaan tekhnologi modern yang mau tidak mau para pendidik, orang tua, murid dan masyarakat harus berusaha menyesuaikan cara pembelajaran yang baru dan dengan penyesuaian kurikulum yang baru pula. Dengan adanya wabah ini ternyata dapat merubah pola pendidikan lama kearah pola pendidikan baru yang kesemuanya tidak terlepas dari adanya perubahan kurikulum juga, Dasar pentingnya perubahan kurikulum adalah: pertama, menjawab atau mengantisipasi kemajuan teknologi dan ilmu pengetahuan. Kedua, penuhi kebutuhan masyarakat dan promosikan kemajuan sosial. Ketiga, memenuhi kebutuhan siswa yang cenderung siswa akan mengikuti pola perkembangan jaman yang selalu kearah perkembangan tekhnologi, seperti sekarang ini suka tidak suka siswa dan orang tua Siswa serta tenaga pengajar (guru) dipaksa untuk melek tekhnologi karena harus melakukan pembelajaran dirmh (daring) karena adanya pandemi COVID 19 yang melanda dunia termasuk Negara Indonesia.
\end{abstract}

Kata kunci: Perubahan, Pola Pendidikan, Covid 19

\begin{abstract}
ABTRAC
At the end of 2019 the emergence of an outbreak or a new virus called Covid 19 that hit the city of the People's Republic of China which in the end the impact also reached the whole world very quickly, this outbreak is very dangerous because it can lead to death and due to this outbreak the death rate is so high almost around the world as well as the State of Indonesia which was also affected by this outbreak which entered in early 2020, this has a huge impact on economic, social, cultural and political life in Indonesia, in this paper the author will describe the consequences of the covid virus that occurred in Indonesia, especially in Indonesia. the field of education in general has changed very drastically from the old pattern, namely face-to-face by adjusting the existing learning curriculum to change to online learning patterns that lead to the use of modern technology which inevitably means that educators, parents, students and the community must try to adjust the way of learning new and with new curriculum adjustments as well. With this epidemic, it turns out that it can change the old education pattern towards a new education pattern, all of which cannot be separated from the change in curriculum as well. The basic importance of curriculum change is: first, responding to or anticipating advances in technology and science. Second, meet community needs and promote social progress. Third, meet the needs of students who tend to follow the developmental patterns of the times which are always directed towards technological developments, such as today, like it or not, students and parents Students and teachers are forced to be literate in technology because they have to do online learning because of the COVID 19 pandemic that has hit the world, including the State of Indonesia.
\end{abstract}

Keywords: Change, Education Pattern, Covid 19 


\section{PENDAHULUAN}

Pada dewasa ini eksploitasi ilmu pengetahuan dan tekhnologi khususnya bidang tekhnologi komunikasi dan informasi (TIK) berkembang sangat pesat memicu dan memacu globalisasi yang meniadakan batas-batas ge ografis (borderless) sekalipun demikian kondisi obyektif menunjukan Indonesia hrus lebih giat dan lebih serius membenahi SDM terutama generasi mudanya. (Ersis Warmansyah Abbas/Metode Guru sekumpul inovasi Pembelajaran IPS berbasis budaya lokal). Disini sangatlah jelas bahwa diawal tahun 2020 pola pendidikan di Indonesia berubah secara total karen diakibatkan adanya bencana Virus covid 19 yang memaksa siswa, guru menggunakan tekhnologi pembelajaran jarak jauh.

Pembelajaran jarak jauh ini memerlukan kretaifitas Guru dalam segala hal karena guru merupakan ujung tombak dari sebuah keberhasilan pendidikan, Guru bukan hanya fasilitator bagi siswa tapi guru juga bisa menjadi fasilitator masyarakat yang kebanyakan adalah orang tua dari para siswa yang juga sangat memerlukan pembelajaran bagaimana menerapkan pola pembelajaran bagi anak-anak mereka dirumah, untuk itu guru harus bisa menulis yang nantinya tulisan tentang apapun mengenai pendidikan dapat di baca oleh semua masyarakat, seperti yang dikatakan salah satu dosen unlam "Semua orang yang menggunakan panca indranya adalah penulis, inputan informasi raupan panca indra manakala di godok diotak terjadilah proses menulis, syukur apabila menjadi konsep tulisan yang akan lebih mudah disalin menjadi tulisan, Menulis berarti menginput informasi (menulis di otak) memproses informasi (menulis di otak) dan menyalinnya dalam tulisan." "Ersis Warmansyah Abbas "(menulis era covid-19 :memanage Trauma spikologis Menghindari Psikosomatis, 2020.

Adanya pandemi COVID 19 atau wabah virus corona ini merupakan keluarga virus yang menyebabkan penyakit yang menyerang paru-paru atau pernapasan dari gelala ringan sampai gejala berat seperti Middle East Respiratory syndrome (MERS) dan severe Acute Respiratory Syndrome (SARS) (Kementrian Kesehatan , 2020) yang mengakibatkan kematian tidak hanya dirasakan pada sektor kesehatan tetapi juga merambah disegala aspek kehidupan, termasuk dunia pendidikan hampir sebagian besar negara yang terpapar virus tersebut meliburkan dan memindahkan aktivitas belajar siswa sekolah ke rumah. Siswa melakukan aktivitas belajar dari rumah sebagai pengganti siswa tidak dapat belajar di sekolah. Hal ini dilakukan sebagai jalan untuk memutus mata rantai penyebaran Covid-19 dengan dikeluarkannya Peraturan Pemerintah (PP) no. 2 Tahun 2020 Tentang Pembatasan Sosial Berskala Besar dalam rangka percepatan penanganan Corona Virus Disease 2019 (Covid-19) dan Keputusan Presiden Republik Indonesia No. 11 Tahun 2020 tentang Penetapan kadaruratan Kesehatan Masyarakat Corona Virus Desease 2020 (Covid-19) Sementara Kementrian Pendidikan dan Kebudayaan Menerbitkan dua surat edaran terkait pencegahan dan penanganan virus tersebut, yang pertama surat edaran no. 2 tahun 2020 tentang penanganan dan pencegahan Covid-19 dilingkungan kemendikbud dan surat edaran no. 3 tahun 2020 tentang pencegahan covid 19 pada satuan pendidikan.

Dalam siaran pers tanggal 24 Maret 2020 mendikbud Nadiem Makarim menyatakan Kebijakan belajar dari rumah di tengah pandemi Covid-19 juga berlaku di Indonesia dengan 
mengeluarkan surat edaran (SE) Mendikbud No. 4 Tahuin 2020 tentang pelaksanaan Kebijakan Pendidikan dalam Masa Darurat Penyebaran Covid 19 yang salah satu isi SE tersebut adalah memberikan himbauan untuk belajar dari rumah melalui pembelajaran daring atau pembelajaran jarak jauh dengan bantuan tekhnologi modern dan internet. Dimasa tanggap darurat seperti ini banyak yang dapat dilakukan oleh Guru dalam menyukseskan "Program belajar dari rumah" dengan lebih memanfaatkan tekhnologi dan kreatifitas dari Guru tersebut. Pada saat sekarang ini pun kita sebagai seorang pendidik dituntut untuk lebih bisa berkreatifitas sendiri dimana selain kita membuat metode-metode pembelajaran yang menyenangkan seperti membuat kuis,tanya jawab,tebak kata, ular tangga dan masih banyak lagi metode pembelajaran yang kita buat untuk siswa sehingga siswa tidak merasa bosan dan menganggap pembelajaran daring itu sebagai momok yang menakutkan terutama anak-anak didik tingkat sekolah dasar dan menengah.

Mereka masih dalam karekteristik anak-anak yang usia bermain sambil belajar, selain itu juga guru diharapkan terus berkarya dari rumah dengan mencoba menyalurkan atau menuangkan ide-ide pemikiran mereka buat dunia pendidikan seperti penulis pernah membaca satu karya tulisan salah satu dosen Unlam yaitu Prof.Dr.Ersis warmansyah abbas, MPd yang berjudul "menulis artikel jurnal" pada isi jurnal tersebut ada kalimat yang membuat saya terkesan beliau berkata "Pokoknya kalau berbicara bak menjadi orang yang paling benar dan hebat di dunia" tetapi tidak sedikit orang terseok-seok pada saat menulis dan manakala ada tagihan menulis sehingga berbagai alasan terbaik mengemuka (Abbas, E.W, 2020) jadi penulis pun mencoba belajar menuliskan pada artikel ini sebagai salah satu langkah yang dapat menjadi aspirasi sesama pendidik atau orang tua siswa dan masyarakat yang selama pendemi covid-19 ini mereka semua terkejut dan belum siap menerima perubahan pola pendidikan dan masih bingung dalam memberikan bimbingan kepada anakanak mereka dalam mengerjakan tugas yang diberikan guru-guru mereka lewat pembejaran daring seperti aplikasi geogle classroom, geogle form, geogle met dan zoom.

"Saya merasa belum menjadi Guru yang sempurna dengan model pembelajaran online karena saya terbiasa belajar dengan tatap muka rasanya lebih bermakna, dengan tatap muka langsung kami lebih dekat dan mengerti jiwa anak, demikian pula dengan anak, mereka lebih merindukan guru dan temannya dalam belajar, membangun karakter anak sangat memerlukan peran serta guru dan orang tua sementara belajar on line lebih cendrung sebagai pola pengajaran." Pendapat ini lah yang sering penulis dengar dari beberapa rekan guru sesama pengajar dimana mereka pun sebenarnya merindukan pembelajaran tatap muka yang selama ini mereka lakukan karena dengan cara tatap muka tersebut akan terjalin emosi antara anak didik dan gurunya dan jua mereka dapat besosialisasi dengan teman-temannya sehingga terjalinnya ikatan emosi yang kuat dan ini tidak kita dapat kan dari sistem pembelajaran daring yang mana mereka dihadapkan dengan mesin yang hanya menghubungkan mereka dengan guru dan teman-temannya selama pembelajaran berlangsung. 


\section{PEMBAHASAN}

Dari penjelasan diatas sudah bisa disimpulkan tidaklah mudah merubah pola pembelajaran lama yag sudah dilakukan selama turun temurun selama berpuluh puluh tahun, yang pada dasarnya pembelajaran dilakukan dilingkungan sekolah dan aktifitas pembelajaran dilakukan didalam ruangan ataupun diluar ruangan, tetapi harus ada kontak sosial antara guru dan murid dan juga murid dengan murid sehingga terjalinnya kontak emosi yang kuat. Tetapi diawal 2020 siswa dan guru serta orang tua siswa dan masyarakat dihadapkan dan diharuskan mengikuti pola pendidikan yang baru yaitu sistem pendidikan jarak jauh dimana siswa belajar dari rumah dan gurupun memberikan pembelajaran dari rumah yang di hubungkan dengan penggunaan tekhnologi dan internet, hal ini mengakibatkan banyak diantara oarng tua yang berusaha menyiapkan segala pasilitas anaknya untuk menghadapi pembelajaran jarak jauh ini seperti mereka membelikan HP atau notebook atau laptop yang mempunyai askes internet sehingga mereka dapat mengikuti pembelajaran daring tersebut.

Biaya untuk pembelajaran daring siswa disekolah ini sangatlah besar karena menggunakan askes internet maka tidak sedikit orang tua yang mengeluh bahwa biaya kehidupan mereka sehari-hari bertambah banyak sedangkan pada masa covid 19 ini ekonomi juga menurun, hal ini berlaku diperkotaan maupun dipedesan hampir diseluruh wilayah Indonesia, sedangkan kita ketahui Indonesia merupakan negara berkembang sebagian besar masyarakatnya adalah ekonomi kelas menengah kebawah, jangankan untuk beli kuota internet buat keperluan makan sehari-hari mereka sangatlah kesulitan, Proses pembelajaran daring sebenarnya tidak mudah diberlakukan di Indonesia. Dalam proses pelaksanaannya, banyak keterbatasan dan permasalahan yang terjadi di lapangan. Menurut pengamatan dan refleksi penulis dari berbagai sumber, ada beberapa kendala dalam melaksanakan pembelajaran daring di Indonesia.

Proses pembelajaran daring sebenarnya tidak mudah diberlakukan di Indonesia dalam proses pelaksanaannya banyak keterbatasan dan permasalahan yang terjadi dilapangan, menurut pengamatan dan refleksi penulis dari beberapa sumber, ada beberapa kendala dalam melaksanakan pembelajaran daring di Indonesia, yaitu :

a. Masih banyak guru yang mempunyai keterbatasan dalam askes pembiasaan tekhnologi banyak diantara mereka yang tidak melek tekhnologi dan banyak pula diantara mereka yang kurang terampil dalam mengolah materi pembelajaran dengan memanfaatkan tekhnologi . Kreativitas ini tidak hanya dari sisi pembuatan konten materi yang menarik, tetapi juga kreativitas dalam memanfaatkan kelebihan media daring yang digunakan. Artinya, guru harus pintar mengkreasi materi pelajaran agar mudah dipahami dan kesannya menyenangkan siswa dengan memanfaatkan media daring yang ada dimana mereka seperti mendapatkan permainan ataupun hiburan yang sebenarnya itu adalah materi pembelajaran yang disisipkan oleh guru tersebut, hal ini yang akan membuat peserta didik semangat dalam pembelajaran daring tetapi diharapkan bagi guru yang melek tekhnologi dan Guru yang ahli dalam pembuatan konten pembelajaran daring diharapkan dapat memberikan ilmu nya dan sedikit membimbing rekan kerjanya agar kegiatan Daring siswa dapat berjalan dengan lancar. 
Pada saat sekarang ini tenaga pengajar seperti Guru sangatlah diperlukan kenapa? “ karena walaupun perserta didik dirumahkan guru harus tetap mengajar seperti biasa karena guru mempunyai peranan yang sangat strategis dan penting dalam keseluruhan upaya pendidikan. Hampir semua usaha pembaharuan di bidang kurikulum dan penerapan metode mengajar guru pada akhirnya tergantung pada guru itu sendiri, Guru adalah orang membuat dan melaksanakan proses dalam pembelajaran tersebut dan menilai setiap peserta didik serta membimbing peserta didik untuk meraih cita-cita dan memiliki akhlak yang baik ( Nur, A.M 2011). Pada sisi inilah peranan guru sangat penting dalam melaksanakan kurikulum, disini penulis ingin menjelaskan apa yang dimaksud dengan kurikulum, dimana kurikulum dipahami sebagai susunan mata pelajaran yang diajarkan pada jenjang pendidikan, secara sederhana pernyataan tersebut tidak sepenuhnya keliru namun pernyataan ini harus diperdalam karena kurikulum tidak hanya berkenaan dengan mata pelajaran. Menurut UU no.20 tahun 2003 pasal 1 ayat (19) Kurikulum adalah seperangkat rencana dan pengaturan mengenai tujuan, isi dan bahan pelajaran serta cara yang dilakukan sebagai pedoman penyelenggaraan kegiatan pembelajaran untuk mencapai tujuan pendidikan tertentu (Syaharuddin, S dan Mutiani, M. 2020).

Dasar pentingnya perubahan kurikulum adalah (1) menjawab atau mengantisipasi kemajuan ilmu pengetahuan dan tekhnologi, (2) memenuhi kebutuhan masyarakat dan mempromosikan kemajuan sosial (3) memenuhi kebutuhan siswa yang cenderung mengikuti pola perkembangan jaman yang selalu mengarah pada penggunaan tekhnologi seperti sekarang ini dimana para siswa, Guru, Orang Tua Siswa dan Masyarakat suka atau tidak suka diharuskan menggunakan tekhnologi untuk melakukan pembelajaran dirmh dengan media internet (Daring) karena adanya pandemi Covid-19 ini.

Pada dewasa ini eksploitasi Ilmu Pengetahuan dan Tekhnologi khususnya dibidang tekhnologi komunikasi dan Informasi (TIK) berkembang sangat pesat memicu dan memacu globalisasi yang meniadakan batas-batas geografi (borderlees) sekalipun demikian kondisi obyektif menunjukan Indonesia harus lebih giat dan lebih serius membenahi SDM terutama generasi mudanya . (Ersis Warmansyah Abbas/Metode Guru sekumpul inovasi Pembelajaran IPS berbasis budaya lokal).

b. Kemandirian belajar siswa dirumah tidak sepenuhnya dapat terlaksana dengan baik kemandirian belajar merupakan tuntutan yang harus dipenuhi dalam pembelajaran Daring, dimana keterbatasan tatap muka dengan Guru dalam pemberian materi dilakukan dengan menggunakan Vide, Geogle classroom, geogle form, geogle mett, WA, media Zoom dll hal ini mengakibatkan siswa harus mandiri dalam memahami materi dan melaksanakan tugas yang diberikan oleh guru. Dalam memahami materi dan mengerjakan tugas tersebut tentunya tidak semulus dan semudah yang dibayangkan karena ketidak pahaman dan miskonsepsi suatu materi mungkin saja akan terjadi apalagi jika materi yang diberikan butuh penjelasan yang detail dan mendalam. Disini sebenarnya peran orang tua siswa sebagai pendamping belajar siswa dirumah mereka harus paham dan bisa membimbing anaknya dalam pembelajaran daring tersebut, tetapi kendalanya kebanyakan orang tua siswa sibuk dengan kegiatan mereka masing-masing dan kebanyakan dari mereka juga tidak 
memahami tentang materi yang diberikan oleh guru. Dan yang lebih parah lagi adalah Daring pada tingkat sekolah Dasar dimana kebanyakan tugas daring dikerjakan orang tua siswa dengan alasan anak" mereka sangat susah untuk mengerjakan tugas daring apalagi lama kelamaan pembelajaran daring ini membosankan bagi anak-anak didik.

c. Tugas dan pekerjaan rumah yang diberikan guru membebani siswa. Pembelajaran daring selayaknya tidak membebani siswa dalam belajar. Siswa harusnya mempunyai kebebasan dalam aktivitas belajarnya. Tidak tertekan dengan banyaknya tugas dan waktu penugasan yang pendek. Termasuk juga dikejar-kejar dengan deadline pengumpulan tugas yang diberikan oleh guru. Artinya, materi dan jenis penugasan selayaknya diberikan waktu yang bijak dan sebisa mungkin terkait dengan kesadaran bahaya wabah Covid-19. Diharapkan Guru dan pihak sekolah bisa menyesuaikan dengan keadaan spikis siswa yang cenderung mereka akan stres apabila mereka di jejali dengan tugas yang banyak dan kemungkinan mereka pun tidak mengerjakan tugas yang diberikan oleh guru tersebut, dengan demikian pemberian tugas harus lah bisa memahami tingkat pemahaman siswa, seperti yang dialami penulis dimana pemberian tugas kepada anak sekolah dasar tentunya beda dengan pemberian tugas pada anak tingkat menengah dan anak tingkat atas, disinilah peran kreatifitas pendidikan dalam mengelola dan membuat materi pembelajaran daring yang lebih modern disesuiakan dengan tingkat pendidikan anak, jangan sampai anak-anak tingkat sekolah dasar diberikan tugas yang begitu rumit dengan memberikan materi pembelajaran melalui video, geogle clasrrom, geogle met dll dimana mereka tidak diberi pengarahan cara menjawab pada aplikasi modern tersebut dan orang tua peserta didik tersebut pun tidak paham penggunaan aplikasi tersebut disini perlu adanya pembelajaran atau penjelasan dulu cara penggunaannya oleh tenaga pengajar dan pihak sekolah agar tidak terjadi kesalahan komunikasi.

d. Dalam pembelajaran Daring HP adalah alat yang harus dan wajib dimiliki oleh anak didik tetapi tidak semua anak didik mempunyai alat komunikasi tersebut, karena tidak semua orang tua siswa mampu membelikan anaknya disinilah kendala yang terbesar dalam pendidikan Daring yang kita laksanakan sekarang.

e. Pembelajaran daring terkendala dengan signal internet yang tidak stabil dan pulsa (kuota data) yang mahal. Kita tahu, bahwa Indonesia adalah negara berkembang dimana ekonomi terbesar masyarakatnya golongan menengah kebawah yang cendrung berpenghasilan kecil ditambah lagi Indonesia mempunyai kondisi geografis yang beragam. Keragaman kondisi letak geografis rumah siswa yang beragam menjadi masalah terutama terkait kestabilan signal internet. Rumah siswa ada yang di dataran rendah, seperti dataran biasa dan tepi laut. Ada juga siswa yang tinggal di dataran tinggi, seperti di pegunungan atau lereng gunung. Ada yang tinggal di kota Dan, ada pula siswa yang tinggal di desa. Kestabilan signal internet diperlukan agar dalam proses pembelajaran tidak terganggu sehingga siswa dapat mengikuti pembelajaran dengan baik. 


\section{KESIMPULAN}

Penyebaran virus Covid 19 yang mematikan yang hampir seluruh dunia mengalamianya juga masuk ke Indonesia pada awal tahun 2020 sehingga Indonesia juga terdampak virus ini dan merubah segala aspek kehiupan masyarakat Indonesia terutama di bidang ekonomi, sosial, budaya dan pendidikan. Pola pendidikan di Indonesia pun berubah sesuai dengan surat edaran (SE) Mendikbud No. 4 Tahuin 2020 tentang pelaksanaan Kebijakan Pendidikan dalam Masa Darurat Penyebaran Covid 19 yang salah satu isi SE tersebut adalah memberikan himbauan untuk belajar dari rumah melalui pembelajaran daring atau pembelajaran jarak jauh dengan bantuan tekhnologi modern dan internet. Dengan adanya surat edaran tersebut sejak akhir bulan maret sekolah diliburkan dimana para siswa dan tenaga pengajar melakukan kegiatan pembelajaran dari rumah atau jarak jauh (Daring) dengan memanfaatkan tekhnologi modern. Banyak kendala yang terjadi pada masa pembelajaran jarak jauh ini yang sebenarnya harus sama-sama disikapi oleh pihak pendidik, siswa, orang tua siswa, masyarakat, pihak terakit dalam dunia pendidikan dan pemerintah sehingga pelaksananaan pembelajaran Daring ini berjalan dengan lancar.

Guru sebagai pasilitator dalam dunia pendidikan diharapkan mampu memberikan pembelajaran di era pandemi ini sekreatif mungkin dan mampu memberikan materi-materi pembelajaran yang mengarah pada pembelajaran yang menyenangkan sehingga siswa merasa senang dan merasa pembelajaran seperti mereka bermain dan merasa rilex dan tidak terbebani walaupun mereka belajar dari rumah dengan sistem Daring, Dan juga Guru diharapkan bijaksana dalam memberikan tugas di era covid 19 ini dengan memberikan tugas yag diperkirakan anak didik mampu mengerjakannya dan diberikan batas waktu yang panjang sehingga anak didik bisa waktunya untuk kegiatan bermain dan tidak belajar secara terus menerus. Guru sebagai tenaga pendidik yang ahli dan kreatif dapat mentransfer ilmunya kepada rekan sejawatnya baim dalam bentuk pembelajaran langsung ataupun dengan cara menulis dan hasil tulisan di share dimedia sosial sehingga rekan seprofesi dan masyarakat dapat mengikuti pola dan ilmu tersebut dalam pelaksanaan daring disekolah-sekolah mereka dan dilingkungan masyarakat seperti orang tua siswa paham dan mengerti cara membimbing anak-anak mereka dalam pembelajaran daring. Seperti yang dikemukakan salah satu dosen Unlam Pak Ewa mengatakan “ Menulis itu sangat mudah dimana setiap orang menuliskan raupan panca indranya di otak atau menyimpannya di memori, Apa yang dilihat, didengar, dicium,di kecap dan diraba ditulis diotak, Misalnya sampean mendengar penjelasan dosen diruang kuliah, diapakan penjelasan tersebut? Disimpan diotak langkah pertama disimpan diotak dulu dan nanti kita ketik dikomputer atau laptop dan jadilah sebuah karya tulis yaitu sebuah buku (Abbas, E.W. 2020).

Tantangan bagi tenaga pendidik sekarang adalah menulis yang dianggap sesuat yang sangat sulit, tapi sebenarnya apabila sudah terbias menulis tdk begitu sulit karena menulis itu sesuatu yang diolah oleh otak dan dituangkan dalam kata-kata “ Setiap orang adalah penulis ya siapa saja selama otaknya sehat dia adalah penulis bukan saja karena otak kumpulan setriliyun atau ada yang menulis 100 juta neorun 
(sel syaraf) yang mana setiap neuron mampu berkoneksi 20,000 sehingga kalkulator manapunsusah mengatur kemampuan otak" (Ersis Warmansyah Abbas , Menulis kenangan menulis buku bersama, universitas lambung mangkurat, 2020).

Pembelajaran Daring banyak memiliki kelemahan seperti anak didik harus mempunyai HP sebagai sarana utama dalam menerima pembelajaran dan tugas yang diberikan oleh Guru, sementara tidak semua anak didik mampu yang orang tuanya dari golongan tidak mampu sehingga mereka yag tidak meiliki HP tdk dapat mengikuti pembelajaran Daring ini ditambah dengan pembelian Kuota internet yang tidak sedikit mengeluarkan biaya tambahan ekonomi keluarga mereka, walaupun siswa mendapatkan kuota gratis dari pemerintah tapi sering tidak mencukupi dalam pemakaiannya dan permasalahan lain adalah askes internet yang tidak semua daerah lancar dalam penggunaannya dimana di Indonesia keadaan Geografisnya beraneka ragam sehingga kadangkala askes internet sulit untuk diterima atau digunakan oleh peserta didik yang jauh dari perkotaan.

Melihat kendala yang ada diatas sangat diharapkan peserta didik mempunyai motivasi yang tinggi untuk mencari ilmu dan mengikuti pembelajaran dengan baik, Motivasi sebagai daya penggerak individu untuk menimbulkan kelangsungan pembelajaran ke arah yang lebih baik, dengan demikian mahasiswa atau peserta didik memiliki motivasi pada tingkat belajar yang lebih tinggi pula sehingga mempercepat hasil yang akan dicapai seperti pembelajaran yang dilakukan secara daring. (Rahman, A.M, Mutiani,M. Dan Putra ,M.A.H, 2019) 


\section{DAFTAR PUSTAKA}

Abbas, E.W, (2020) Menulis diotak dan menuliskan Tulisan di Otak

Ersis Warmansyah Abbas menulis era covid-19 :memanage Trauma spikologis Menghindari Psikosomatis, 2020

Abbas, E.W, (2020) Menulis kenangan menulis buku bersama, Menulis kenangan menulis buku bersama

Abbas, E.W, (2020) Menulis artikel jurnal, menulis artikel jurnal

Ersis Warmansyah Abbas, (Menulis kenangan menulis buku bersama, universitas lambung mangkurat, 2020).

Kementrian kesehatan (2020) pedoman pencegahan dan pengendalian coronavirus Disease (Covid 19)

Nur, A.M (2011) Tugas Guru sebagai pengembang kurikulum JURNAL ILMIAH DIDAKTRA Media Ilmiah Pendidik dan pengajaran, 12 (1) 59-67

Rahman, A.M, Mutiani, M. \& Putra M.A.H (2019) pengaruh kompetensi pedagogik dosen terhadap motivasi belajar mahasiswa pendidikan IPS , jurnal Darussalam, jurnal pendidika, komunikasi dan pemikiran Hukum Islam, 10(2), 375-387

Syaharudin, S (2020)Menimbang peran tekhnologi dan Guru dalam pembelajaran di Era Covid 19 menimbang peran tekhnologi dan Guru dalam pembelajaran di era Covid-19

Buku berjudul Covid-19 dalam ragam tinjauan perspektif oleh Wakhudin (tim), editor Didik Suntoso, penerbit Mbridge Press, Juni 2020 